\title{
Asymptomatic progressive multifocal leukoencephalopathy: a case report and review of the literature
}

\author{
Yinan Zhang ${ }^{*} \mathbb{D}$, Crystal Wright and Angela Flores
}

\begin{abstract}
Background: We report the development of asymptomatic progressive multifocal leukoencephalopathy in a patient with multiple sclerosis on natalizumab therapy. Progressive multifocal leukoencephalopathy often presents with debilitating neurologic symptoms. Very few cases have documented a completely asymptomatic course of the disease.

Case presentation: A 26-year-old white woman with multiple sclerosis was treated with natalizumab. She was diagnosed as having progressive multifocal leukoencephalopathy based on characteristic magnetic resonance imaging lesions after 27 infusions of natalizumab. She had no neurologic deficits at the time of diagnosis and John Cunningham virus in cerebrospinal fluid was detected at 15 copies $/ \mathrm{ml}$. She was initially treated with mefloquine and mirtazapine and remained asymptomatic for 3 months. She later developed worsening magnetic resonance imaging lesions related to immune reconstitution inflammatory syndrome. At that time, she received intravenously administered immunoglobulin and high-dose intravenously administered methylprednisolone with radiologic improvement of the lesions.

Conclusions: Our case report illustrates that early detection of asymptomatic progressive multifocal leukoencephalopathy and its subsequent treatment resulted in a benign clinical course. In consideration of the additional small number of cases of asymptomatic progressive multifocal leukoencephalopathy that have been reported, we conclude that routine magnetic resonance imaging surveillance is important for patients with multiple sclerosis who are at high risk for developing natalizumab-associated progressive multifocal leukoencephalopathy.
\end{abstract}

Keywords: Multiple sclerosis, Natalizumab, Progressive multifocal leukoencephalopathy, Magnetic resonance imaging

\section{Background}

Progressive multifocal leukoencephalopathy (PML) is the leading adverse effect from using natalizumab in the treatment of multiple sclerosis (MS). PML is a progressive multifocal disease involving the white matter and typically presents with subacute onset of symptoms including altered mental status, visual and motor deficits, and ataxia [1]. Natalizumab-associated PML carries an average mortality of $23 \%$ and survivors often develop debilitating neurologic deficits from the disease and its treatment sequelae, such as immune reconstitution inflammatory syndrome (IRIS), in which there is a paradoxical worsening

\footnotetext{
*Correspondence: yinan.zhang@phhs.org

Department of Neurology and Neurotherapeutics, University of Texas

Southwestern Medical Center, 5323 Harry Hines Blvd, Dallas, TX 75390, USA
}

of the infection due to overwhelming inflammatory reaction by the recovering immune system after discontinuing the immunosuppressing agent [2]. PML is caused by John Cunningham virus (JCV), and patients on natalizumab therapy receive serum JCV antibody index testing and surveillance with interval magnetic resonance imagings (MRIs) to assess PML risk and detect early stages of the disease. PML is seen on MRI as multifocal, asymmetric periventricular and subcortical lesions with minimal mass effect or enhancement [3]. Despite measures of clinical vigilance, PML often presents with new neurologic deficits prior to its diagnosis.

We report the case of a patient diagnosed as having PML based on characteristic MRI lesions from a routine surveillance scan who was clinically asymptomatic at the

(c) The Author(s). 2018 Open Access This article is distributed under the terms of the Creative Commons Attribution 4.0 International License (http://creativecommons.org/licenses/by/4.0/), which permits unrestricted use, distribution, and reproduction in any medium, provided you give appropriate credit to the original author(s) and the source, provide a link to the Creative Commons license, and indicate if changes were made. The Creative Commons Public Domain Dedication waiver (http://creativecommons.org/publicdomain/zero/1.0/) applies to the data made available in this article, unless otherwise stated. 
time of diagnosis and continued to have minimal disability throughout the course of the disease.

\section{Case presentation}

A 26-year-old right-handed white woman with no significant medical history was diagnosed as having MS in 2013 at age 22 and experienced ongoing radiologic activity on both glatiramer acetate and dimethyl fumarate. She transitioned to natalizumab in July 2014 to stabilize disease activity, and her JCV antibody index was positive at 3.58 prior to starting natalizumab. She became clinically and radiologically stable with the initiation of natalizumab until November 2016 when a surveillance MRI of her brain showed asymmetric confluent non-enhancing hyperintensities in the bilateral subcortical precentral gyri consistent with PML (Fig. 1a, b). Cerebral spinal fluid (CSF) showed quantitative polymerase chain reaction (PCR) for JCV of 15 copies $/ \mathrm{ml}$, and other CSF studies were within normal limits. A diagnosis of PML was made based on the compatible neuroimaging findings along with the presence of JCV DNA in the CSF. Natalizumab was discontinued after 27 total treatments. Our patient was asymptomatic at the time of PML diagnosis, and she was highly functioning with an Expanded Disability Status Scale (EDSS) of 0. A decision was made to defer plasmapheresis at the time of diagnosis given her high functional status, subtle radiological change, and low viral titer. She was treated with orally administered mefloquine loading dose followed by $250 \mathrm{mg}$ weekly and mirtazapine $15 \mathrm{mg}$ daily.

Repeat MRI at 2 months following diagnosis showed no changes in her brain lesions. She remained asymptomatic until 3 months after diagnosis when she noticed mild dysmetria of her left hand that progressed to a tremor. The following month a repeat brain MRI revealed a few small enhancing lesions in her left frontal lobe suggestive of IRIS (Fig. 1c, d). The hyperintensities in the bilateral precentral gyri remained stable. Imaging of her cervical spine revealed a new non-enhancing cord lesion. She was then treated for 5 days with intravenously administered immunoglobulin and restarted on glatiramer acetate for MS treatment. A repeat CSF examination in February 2017 showed JCV PCR of 31 copies $/ \mathrm{ml}$.

Five months following her diagnosis, a repeat brain MRI showed interval development of T2 signal abnormality with mild enhancement in multiple areas including the brainstem, cerebellum, and bilateral cerebral hemispheres (Fig. 1e, f). A repeat lumbar puncture was performed. JCV PCR in the CSF was undetectable. Mefloquine and mirtazapine were discontinued. Given the MRI findings, she was treated for ongoing inflammation associated with IRIS versus a possible exacerbation of her underlying MS with high-dose intravenously administered methylprednisolone (IVMP) $1500 \mathrm{mg}$ daily for 3 days. She was then transitioned
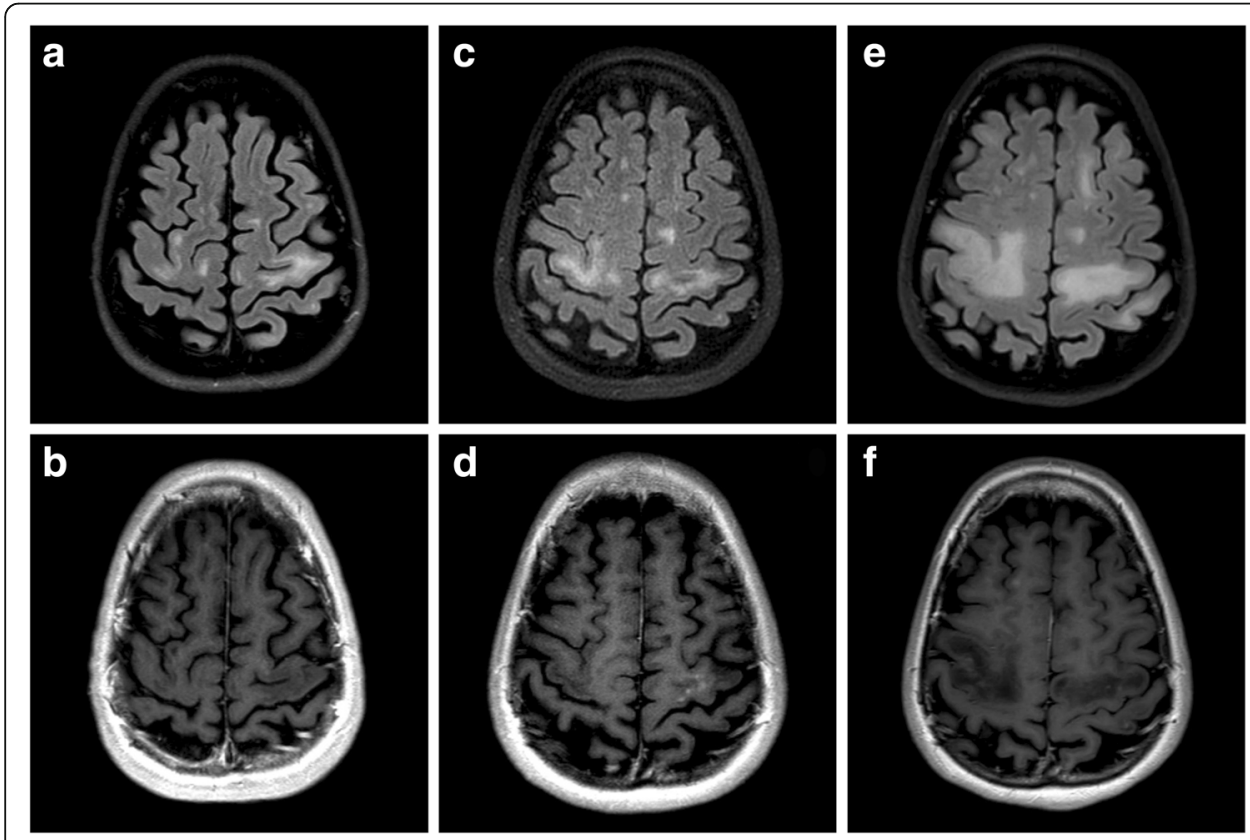

Fig. 1 (a-h) Magnetic resonance imaging T2 fluid-attenuated inversion recovery and post-contrast T1 images of the patient at time of progressive multifocal leukoencephalopathy diagnosis showing bilateral asymmetric confluent non-enhancing hyperintensities in the subcortical precentral gyri $(\mathbf{a}, \mathbf{b})$, at 3 months showing a few small enhancing lesions in the left frontal lobe suggestive of immune reconstitution inflammatory syndrome $(\mathbf{c}, \mathbf{d})$, at 5 months showing interval development of $\mathrm{T} 2$ signal abnormality with mild enhancement (e, $\mathbf{f}$ ), and at 1 year showing further decrease in $\mathrm{T} 2$ hyperintensities and resolution of enhancement $(\mathbf{g}, \mathbf{h})$ 
Table 1 Case reports of natalizumab-associated progressive multifocal leukoencephalopathy with asymptomatic disease course

\begin{tabular}{|c|c|c|c|c|c|c|c|}
\hline $\begin{array}{l}\text { Authors and } \\
\text { Reference number }\end{array}$ & $\begin{array}{l}\text { Age } \\
\text { (years)/sex }\end{array}$ & $\begin{array}{l}\text { EDSS at } \\
\text { diagnosis }\end{array}$ & MRI findings & $\begin{array}{l}\text { Development } \\
\text { of IRIS }\end{array}$ & PML treatment & $\begin{array}{l}\text { CSF JCV } \\
\text { (copies/ml) }\end{array}$ & Risk factors [11] \\
\hline This case report & $26 / F$ & 0 & $\begin{array}{l}\text { Bilateral asymmetric confluent } \\
\text { non-enhancing hyperintensities } \\
\text { in the bilateral subcortical } \\
\text { precentral gyri }\end{array}$ & Yes & $\begin{array}{l}\text { Mefloquine and } \\
\text { mirtazapine }\end{array}$ & 15 & $\begin{array}{l}27 \text { natalizumab } \\
\text { infusions, } \\
\text { JCV-positive, } \\
\text { JCV index } 3.58\end{array}$ \\
\hline $\begin{array}{l}\text { Blinkenberg } \\
\text { et al. [12] }\end{array}$ & $50 / F$ & 3.5 & $\begin{array}{l}\text { Right cerebellar peduncle } \\
\text { hyperintense lesions }\end{array}$ & Yes & $\begin{array}{l}\text { None, PML undiagnosed } \\
\text { until presentation of } \\
\text { PML-IRIS following } \\
\text { natalizumab cessation }\end{array}$ & 552 & $\begin{array}{l}47 \text { natalizumab } \\
\text { infusions, } \\
\text { JCV-positive }\end{array}$ \\
\hline $\begin{array}{l}\text { Fabis-Pedrini } \\
\text { et al. [13] }\end{array}$ & $24 / F$ & 6 & $\begin{array}{l}\text { Mildly enhancing small patchy } \\
\text { lesions in left brainstem, cerebral } \\
\text { peduncle, pontine tegmentum, } \\
\text { and left brachium points }\end{array}$ & Yes & $\begin{array}{l}\text { PLEX, mefloquine, } \\
\text { mirtazapine, prednisone }\end{array}$ & 63,910 & $\begin{array}{l}\text { Treatment with } \\
\text { natalizumab for } \\
54 \text { months, } \\
\text { JCV-positive }\end{array}$ \\
\hline $\begin{array}{l}\text { Mc Govern and } \\
\text { Hennessay [14] }\end{array}$ & $61 / F$ & 0 & $\begin{array}{l}\text { Left posterior parietal } \\
\text { non-enhancing hyperintensity }\end{array}$ & No & PLEX, mirtazapine & 12 & $\begin{array}{l}\text { Treatment with } \\
\text { natalizumab for } \\
3 \text { years }\end{array}$ \\
\hline
\end{tabular}

CSF cerebrospinal fluid, EDSS Expanded Disability Status Scale, F female, IRIS immune reconstitution inflammatory syndrome, JCV John Cunningham virus, MRI magnetic resonance imaging, PLEX plasma exchange, PML progressive multifocal leukoencephalopathy

from glatiramer acetate to ocrelizumab for treatment of MS. Six months following her diagnosis she reported changes in left hand dexterity and right upper extremity phasic spasms. A repeat lumbar puncture was performed and JCV PCR remained undetectable. She continued MRI surveillance followed by treatment with high-dose IVMP for a total of six courses until there was significant resolution of enhancement on her brain MRI (Fig. 1g, h). Following treatment, she has residual left hand dysmetria and tremor as well as right upper extremity phasic spasms. At 1-year follow-up, her EDSS is 2.0.

\section{Discussion}

The patient described in this case report underwent an asymptomatic course of PML treated with mefloquine and mirtazapine. Due to the early discovery of PML in our patient and her intact neurologic examination at the time of diagnosis, we chose not to treat with plasma exchange (PLEX) in order to decrease the speed of immune reconstitution, which has been associated with stronger inflammation in patients with HIV-PML [4]. Further studies showed PLEX conferred no additional benefit of reduced mortality or improved outcome in patients who received PLEX $(n=184)$ versus those who did not $(n=35)$ for treatment of natalizumab-associated PML [5]. The neurologic deficits sustained toward the end of this patient's treatment were thought to be from IRIS rather than the progression of PML lesions. While there is no definitive method of distinguishing PML lesions from those caused by IRIS [6], the presence of gadolinium enhancement on brain MRI along with undetectable JCV favored the diagnosis of IRIS rather than development of new PML lesions.

Although PML usually presents with clinical symptoms at the time of diagnosis, around $8 \%$ of patients with natalizumab-associated PML were asymptomatic at diagnosis, and PML lesions have been reported to present up to 6 months prior to onset of clinical symptoms $[7,8]$. Almost all patients diagnosed as having PML develop neurologic deficits throughout the course of the disease with varying levels of severity. A retrospective case series of 336 patients with natalizumab-associated PML identified factors corresponding to improved survival and favorable outcomes including younger age and lower JCV count at diagnosis, low baseline disability at diagnosis, and localized MRI lesions [9]. Only a few cases have documented an asymptomatic disease course of PML (Table 1). While data from these reports are insufficient to conclude patterns leading to asymptomatic PML course, they illustrate the importance of MRI surveillance in detecting early radiologic evidence of PML prior to the development of clinical symptoms. The frequency of MRI monitoring has been debated and arguments against more frequent use cited the increased cost and limited imaging resources. However, reports have suggested 3-4 months as the optimal surveillance interval for patients at high risk of developing PML [10].

\section{Conclusions}

When diagnosed early and treated, PML can present with a mild or even asymptomatic disease course. Clinical vigilance and routine MRI surveillance is important for patients with MS who are at high risk for developing natalizumab-associated PML.

\section{Acknowledgements}

We wish to thank the patient for consenting to the publication of this case report.

\section{Authors' contributions}

$\mathrm{CW}$ and $\mathrm{YZ}$ wrote the case presentation section of the manuscript. $Y Z$ also wrote all other sections of the manuscript. AF revised the first draft of the manuscript. All authors read and approved the final manuscript. 


\section{Ethics approval and consent to participate}

This case report was approved by the internal research ethics committee of University of Texas Southwestern Medical Center in accordance with the code of ethics of the Declaration of Helsinki.

\section{Consent for publication}

Written informed consent was obtained from the patient for publication of this case report and any accompanying images. A copy of the written consent is available for review by the Editor-in-Chief of this journal.

\section{Competing interests}

Yinan Zhang has no conflict of interests to declare. Crystal Wright is a speaker for Genzyme and Novartis and is involved in a clinical trial with MED Day. Angela Flores is a speaker and consultant for Biogen and Genentech. The authors declare that they have no competing interests.

\section{Publisher's Note}

Springer Nature remains neutral with regard to jurisdictional claims in published maps and institutional affiliations.

Received: 17 January 2018 Accepted: 28 May 2018

Published online: 01 July 2018

\section{References}

1. Tan CS, Koralnik IJ. Progressive multifocal leukoencephalopathy and other disorders caused by JC virus: clinical features and pathogenesis. Lancet Neurol. 2010;9:425-37

2. Clerico M, Artusi CA, Di Liberto A, Rolla S, Bardina V, Barbero P, De Mercanti SF, Durelli L. Long-term safety evaluation of natalizumab for the treatment of multiple sclerosis. Expert Opin Drug Saf. 2017;16:963-72.

3. Garrels K, Kucharczyk W, Wortzman G, Shandling M. Progressive multifocal leukoencephalopathy: clinical and MR response to treatment. AJNR Am J Neuroradiol. 1996;17:597-600.

4. Murdoch DM, Suchard MS, Venter WD, Mhlangu P, Ottinger JS, Feldman C Van Rie A, Glencross DK, Stevens WS, Weinhold KJ. Polychromatic immunophenotypic characterization of T cell profiles among HIV-infected patients experiencing immune reconstitution inflammatory syndrome (IRIS). AIDS Res Ther. 2009;6:16.

5. Landi D, De Rossi N, Zagaglia S, Scarpazza C, Prosperini L, Albanese M, Buttari F, Mori F, Marfia GA, Sormani MP, Capra R, Centonze D, Italian PML study group. No evidence of beneficial effects of plasmapheresis in natalizumab-associated PML. Neurology. 2017;88:1144-52.

6. Honce JM, Nagae L, Nyberg E. Neuroimaging of Natalizumab complications in multiple sclerosis: PML and other associated entities. Mult Scler Int. 2015;2015: 809252.

7. Dong-Si T, Richman S, Wattjes MP, Wenten M, Gheuens S, Philip J, Datta S, Mclninch J, Bozic C, Bloomgren G, Richert N. Outcome and survival of asymptomatic PML in natalizumab-treated MS patients. Ann Clin Transl Neurol. 2014;1:755-64.

8. Blair NF, Brew BJ, Halpern JP. Natalizumab-associated PML identified in the presymptomatic phase using MRI surveillance. Neurology. 2012;78:507-8.

9. Dong-Si T, Gheuens S, Gangadharan A, Wenten M, Philip J, Mclninch J, Datta S, Richert N, Bozic C, Bloomgren G, Richman S, Weber T, Clifford DB. Predictors of survival and functional outcomes in natalizumab-associated progressive multifocal leukoencephalopathy. J Neuro-Oncol. 2015;21:637-44.

10. McGuigan C, Craner M, Guadagno J, Kapoor R, Mazibrada G, Molyneux P, Nicholas R, Palace J, Pearson OR, Rog D, Young CA. Stratification and monitoring of natalizumab-associated progressive multifocal leukoencephalopathy risk: recommendations from an expert group. J Neurol Neurosurg Psychiatry. 2016;87:117-25.

11. Bloomgren G, Richman S, Hotermans C, Subramanyam M, Goelz S, Natarajan A, Lee S, Plavina T, Scanlon JV, Sandrock A, Bozic C. Risk of natalizumab-associated progressive multifocal leukoencephalopathy. N Engl J Med. 2012;366:1870-80.

12. Blinkenberg M, Sellebjerg F, Leffers AM, Madsen CG, Sorensen PS. Clinically silent PML and prolonged immune reconstitution inflammatory syndrome in a patient with multiple sclerosis treated with natalizumab. Mult Scler. 2013;19:1226-9.

13. Fabis-Pedrini MJ, Xu W, Burton J, Carroll WM, Kermode AG. Asymptomatic progressive multifocal leukoencephalopathy during natalizumab therapy with treatment. J Clin Neurosci. 2016;25:145-7.

14. Mc Govern EM, Hennessy MJ. Asymptomatic progressive multifocal leukoencephalopathy associated with natalizumab. J Neurol. 2013;260:665-7.

\section{Ready to submit your research? Choose BMC and benefit from:}

- fast, convenient online submission

- thorough peer review by experienced researchers in your field

- rapid publication on acceptance

- support for research data, including large and complex data types

- gold Open Access which fosters wider collaboration and increased citations

- maximum visibility for your research: over $100 \mathrm{M}$ website views per year

At BMC, research is always in progress.

Learn more biomedcentral.com/submissions 